\title{
MINING
}

UDC 622.271

\author{
S. K. Moldabayev ${ }^{1}$, \\ orcid.org/0000-0001-8913-9014, \\ A. A. Adamchuk ${ }^{2}$, \\ orcid.org/0000-0002-8143-3697, \\ A. A. Toktarov ${ }^{1}$, \\ orcid.org/0000-0003-2578-8642, \\ Ye. Aben ${ }^{1}$, \\ orcid.org/0000-0003-3909-3200, \\ O.O. Shustov ${ }^{2}$, \\ orcid.org/0000-0002-2738-9891
}

https://doi.org/10.33271/nvngu/2020-4/030

1 - Satbayev University, Almaty, the Republic of Kazakhstan, e-mail: s.moldabayev@satbayev.university

2 - Dnipro University of Technology, Dnipro, Ukraine, e-mail: a.a.adamchuk93@gmail.com

\section{APPROBATION OF THE TECHNOLOGY OF EFFICIENT APPLICATION OF EXCAVATOR-AUTOMOBILE COMPLEXES IN THE DEEP OPEN MINES}

Purpose. To establish the feasibility of implementing the technology for working out the overburden rock ledges and ore mining by transverse panels in steeply sloped layers within a single open mine until the end of its operation.

Methodology. In substantiating the spatial position of the staged contours of steeply sloped layers in round-shaped open mine fields and their optimization, the following methods were used: Bellman's analytical and optimal control methods in dynamic programming in combination with an integrated mining and geological information complex basing on a digital model of an iron ore field. To study the reserves of increasing the productivity of excavator-car complexes, when switching to the technology of working out pit banks with transverse panels in steeply inclined layers from top to bottom with a shift of the open pit spacing, methods of correlation and regression analysis were used.

Findings. Based on the distinction between the concepts of the near-contour and deep zones of deep open mines and the introduction of two new parameters for the relationship between the contours of the ore field and the dynamics of the open mine formation, a method of justification of the spatial position of the staged contours of steeply sloped layers in round-shaped open mine fields has been developed. Compared to the dead-end turn of automotive dumping trucks according to the used technology for working out ledges with longitudinal panels, the transition to working them out with transverse panels with a width of $60-80 \mathrm{~m}$, with a loop turn of the automotive dumping trucks for loading will increase the productivity of excavators at least by $25-30 \%$, which, along with a decrease in the spacing of the open mine sides, compensates the intensity of the ore field overburden from top to bottom within the boundaries of steeply sloped layers even with a significant lag of overburden operations.

Originality. The transition to the technology of working out ledges with transverse panels in steeply sloped layers is the only solution if the overburden lag exceeds the current design overburden volumes when mining approaches the limit contour of the open mine surface. In the studied extremely deep iron ore open mine, even when the design volume of the current (annual) overburden operations increases by more than 3 times, this technology allowed reducing the overburden lag by $25 \%$ and shortening the period for the development of the ore production capacity from 8 to 5 years. A mathematical model has been created to optimize the contours of working out stages for steeply sloped fields when working out ledges with transverse panels in steeply sloped layers, in which the functional contains the fourth-order non-linearity in relation to the required value - the width of the panels. Automation of calculations for optimizing the parameters of the design of the working open mine sides in the dynamics of the development of mining operations with such a formulation of the task by non-linear programming method is provided by splitting it into two successively solved optimization tasks by the dynamic programming method on the basis of Bellman's optimality principle.

Practical value. The staged contours of steeply sloped layers, constructed using the method of substantiating the spatial position, for an existing iron ore open mine, after optimization of steep sides using Bellman's optimal control method, will enable one to obtain a real mining operation schedule when implementing the technology for working out ledges for rock overburden and ore mining with transverse panels in steeply sloped layers within a single open mine. It is established that despite the increase in the volume of rock mass in the worked out panel from top to bottom, it is possible to level significantly the volumes of lag of the overburden operations and to shorten the period of the development of production capacity for a strategic iron ore mining facility. Analysis of the mining operation schedule shows that the greatest difficulties arise in the first three years - 2020-2022. The current overburden ratio at mining of 15 million tons of ore will vary from 8.9 to 8.7 tons/ton. However, taking into account the existing overburden lag place, it can be reduced by almost $25 \%$. A two-fold decrease in rock overburden volumes in 2023 will increase the ore mining by $30 \%$ to 19.5 million tons, and in 2024, by $60 \%$, respectively, and develop a design capacity of 24 million tons.

Keywords: deep open mine, overburden and mining operations, steeply sloped layers, transverse panels, automobile transport, excavator-automobile complex

(C) Moldabayev S.K., Adamchuk A.A., Toktarov A.A., Aben Ye.,

Shustov O. O., 2020 
Introduction. During the economic downturn, in many open mines, in order to reduce the volumes of overburden operations for mineral mining, the theoretically and practically well-known method of temporarily suspending of mining operations in separate sections of an overburden area with the formation of temporarily idle sides was applied. One of the negative consequences of their construction is the subsequent decrease in the design production capacity at these open mines, which often leads to a decrease in their competitiveness. To increase their productivity, subsoil users have to attract considerable additional resources and investments. The applied mining technology for the extraction of overburden rock and ore at the studied extremely deep iron ore open mine is characterized by a $2-3$-fold lifting of their rational height and distance of transporting them by automotive dumping trucks. The cramped operating conditions of excavators when working out ledges with longitudinal panels limit their productivity. The transition to the use of more powerful dumping trucks will require a review of the final design contour of an open mine along the earth's surface upwards.

Working in narrow open mine faces makes it difficult to maneuver dumping trucks before loading, and the absence of wide platforms does not allow minimizing the excavator downtime during the delivery of the automotive dumping trucks for loading. Compared to the foreign counterparts, it is $2-2.5$ times less.

Literature review. The analysis of the open mining experience of world-known fields shows that the elements of the open mine contour, namely, the depth and angle of the ledges of an open mine sides extinction, have been revised upward many times due to the improvement of technology, techniques and methods for managing the stability of open mine sides [1]. It is advisable to divide the field reserves established for an open-cast mining by their depth into stages with construction of the intermediate sides of a stage at angles equal to the extinction angle or those closed to it.

The following provisions are the initial principles for managing the condition of open mine sides [2]:

- the sides of the open mine should provide safe (for people and equipment) mining operations;

- the ledges of the open mine sides should ensure the costefficiency of the field development;

- in difficult conditions at great depths of the development, special engineering measures are needed to manage the condition of the open mine sides;

- special services should be created at open mines for monitoring the stability of the sides and monitoring of engineering activities.

A lot of scientific works have been devoted to the application of the principle of minimizing the overburden operations in the model of optimizing the planning of mining operations at open mines, optimizing the position of the working zone in the contours of the round-shaped open mine fields, stabilizing the productivity of the deep open mines by the rock mass and eliminating of the lag in overburden operations $[3,4]$. The desire to minimize the volumes of overburden operations to the detriment of the opened mineral reserves in deep open mines often leads to the overburden lagging, which makes it difficult to maintain production capacity with lower mining operations $[5,6]$. Known methods for the periodic creation of temporarily idle sides in root strong rocks complicate the mining technology and do not always solve the problem of lagging of the overburden operations and the rhythm of their production with mining $[7,8]$.

Analysis of the experience of designing, scientific research and mining in deep open mines allows highlighting the following most important areas for solving the problems of the staged development [9]:

- the formation of optimal profiles of temporarily idle open mine sides;

- the choice of technology for the re-activation of temporarily idle open mine sides, taking into account the creation of fencing structures to ensure safe working conditions protecting equipment and people from pieces of rock that accidentally fall from high slopes and are separated during explosions;

- management of the working area of the open mine and optimization of the open mine space.

During the staged development of steeply sloped fields before mining operations approach the limit surface contour, the temporarily idle sides are formed in almost every open mine. This is due to a decrease in the current volumes of the overburden operations and, accordingly, operating costs [10, 11]. However, the formation of a temporarily idle open mine side significantly complicates the organization of planning and performance of mining operations. Fluctuations in prices and demand for mineral raw materials and instability in the mining industry often lead to untimely re-activation of a temporarily idle open mine side and, accordingly, to a decrease in production capacity of a mineral [12, 13].

Known methods of re-activation of a temporarily idle open mine side with the alternate preparation of working ledges are relatively cheap, but do not always provide timely preparation of mining horizons. Traditional designs of temporarily idle open mine sides provide regulation of the overburden ratio and do not take into account the subsequent method of reactivation.

The experience of using excavator-automobile complexes in open mines $[14,15]$ shows that there is insufficient information on the relationship between the mining technology and performance of excavators and automotive dumping trucks, especially in the deep zone of round-shaped open mine fields. As a rule, practice shows that with the deepening of open mines during working out of an increasing number of ledges by longitudinal panels, the productivity of excavator-automobile complexes sharply decreases [16, 17].

Unsolved aspects of the problem. The productivity of the excavator-automobile complex depends not only on the availability of rock mass ready for excavation, but also on the commensurate development of mining operations on adjacent ledges, the safe operating conditions for operation of automotive dumping trucks, the time of their exchange during loading, the quality of rock crushing, and others. The length of the overburden area is reduced with deepening of excavation works. Therefore, the search for technological methods for maintaining production capacity is still a relevant problem of open cast mining.

Purpose. To establish the feasibility of implementing the technology of working out ledges of overburden rocks and ore with transverse panels in steeply sloped layers within a single open mine until the end of its operation, the influence of this technology on the productivity of excavator-automobile complexes, optimization of the mining operation schedule shortening the time of reaching the production capacity .

Results. In the most developed countries, at large open mines, $77 \%$ of mining work volumes is carried out by excavator-automobile complexes. The emphasis is made on the use of powerful mechanical shovels and heavy automotive dumping trucks. Increasing of the productivity of excavator-automobile complexes significantly reduces operating costs. However, at some open mines, the width of roads reaches 35-40 m, which reduces the efficiency of mining operations due to the increase in the width of working sites. Therefore, by finding methods for an effective use of the powerful excavator-automobile complexes in operation, the tasks on substantiating the reserves of managing the mining regime and, based on it, increasing of the productivity of ore open mines are jointly solved.

When using powerful excavator-automobile complexes, it is preferable to transfer for working out ledges with transverse panels (Figs. 1, 2). The example of the successful implementation of this technology is the open mines of the Escondida big mine in Chile. They are the largest in copper production in the world (more than $9-10 \%$ ). This mine productivity is 


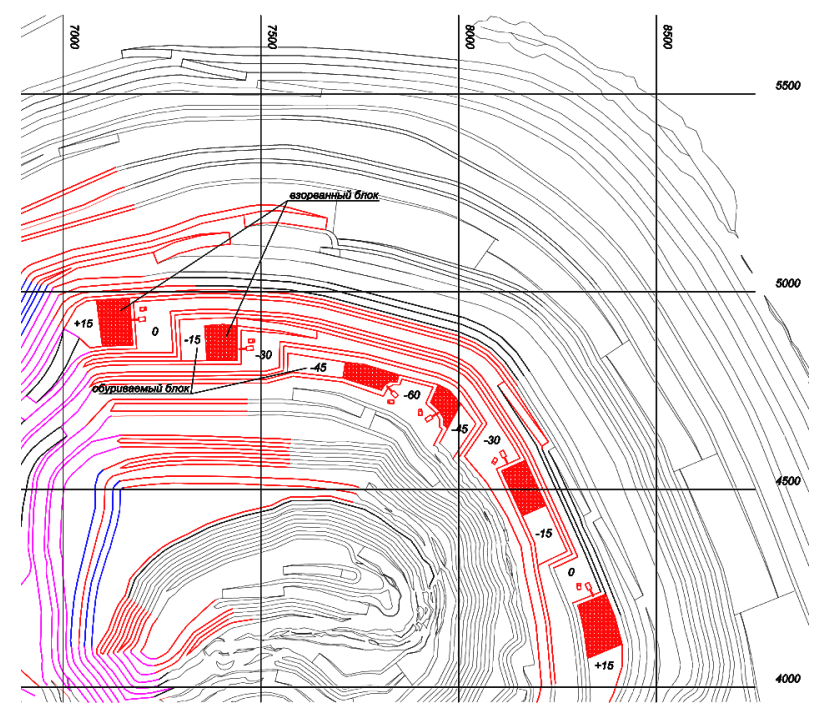

Fig. 1. The technology for working out ledges with transverse panels with loop scheme of supplying automotive dumping trucks for loading

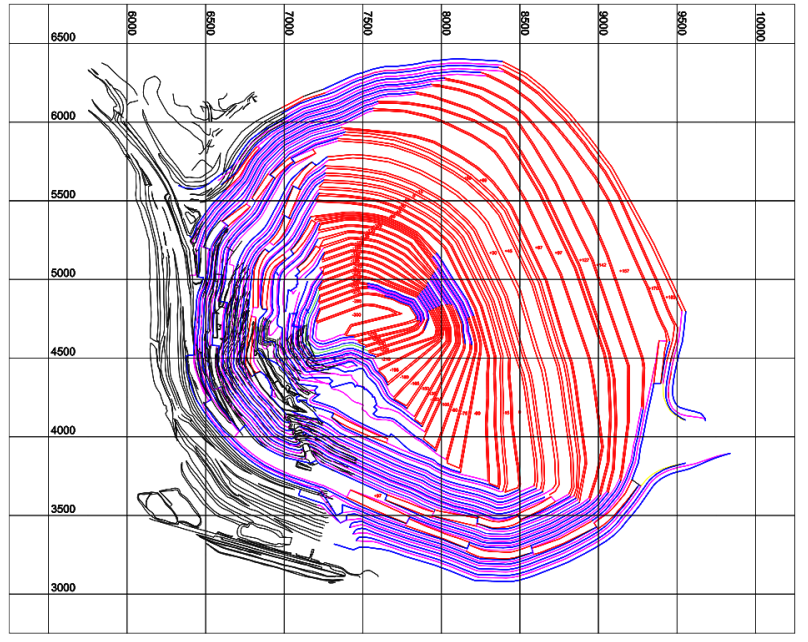

Fig. 2. The scheme for implementation of the technology of working out ledges with transverse panels in steeply sloped layers from top to bottom on rounded-shape open mine fields

135 thousand tons of ore per day or 47.3 million tons of ore per year [18].

The complex's productivity is, in fact, the productivity of the excavator included in it or the summarized productivities of dumping trucks as a whole. Therefore, the calculation of the productivity of excavator-automobile reduces to the calculation of the productivity of an excavator and dumping trucks composing the complex, taking into account their technological and organizational relationship.

The reliability of planning mining operations and the efficiency of implementation of technologies and workforces depend on the accuracy of the complex productivity calculations. At the present time, the common standards for open-cast mining operation productivity rate are used as a basis for operative planning of the loading-transport works and for the labor payment and motivation.

However, they are not accurate enough:

- the relationship between loading and transport link are hardly taken into account;

- the peculiarities of inter-shift organization of the complex as a whole are not taken into account;

- the deviation of the actual working conditions from the standard are taken into account approximately enough.
When calculating the productivity of excavators, their downtime at the beginning of the shift due to waiting for the arrival of automotive dumping trucks and at the end of the shift due to the exit of automotive dumping trucks from the working area for changing drivers is not taken into account. The destination of the rock mass moving and the number of dumping trucks working with the excavator - the factors that determine downtime when waiting for arrival of the next dumping truck, - are not taken into account.

When calculating the performance of automotive dumping trucks, their operating time during the shift is also estimated not accurately enough, the number of vehicles working in conjunction with an excavator, possible downtime waiting in the queue for unloading, transport and operational quality of roads, and the height of the rock mass rising are not accurately estimated. The "reduced distance" indicator used in the common standard of productivity takes into account the properties of automobile transport communications in open mines aggregately enough and therefore does not estimate them accurately.

A significant feature of the mining conditions is the uniqueness of each open mine and each face in it. Consequently, there can be no uniform standards for open-cast mining productivity rates. The current standards can only be used for aggregated calculations at the stage of investment feasibility studies.

The methodological base and methods for calculating the productivity of open mine equipment should be uniform. The standard parameters of the processes should be determined for conditions of each particular open mine on the basis of experimental studies for the current and prospective planning of mining operations. Operational planning should be carried out on the basis of periodic clarification of the standard parameters with the help of timing observations and analysis of the actual level of organization of mining and transport operations and the technical state of the vehicle fleet.

For the studied technology of working out ledges of rock overburden and ore with transverse panels in steeply sloped layers according to the method of driving dumping trucks to the excavator at the edging face (the nature of maneuvers) in the presence of transport berms of the required width and the presence of two transport exits on the ledge, the end-to-end schemes for supply of dumping trucks to the excavator are possible. With the width of a transverse panel within $60-80 \mathrm{~m}$, the most appropriate scheme for supplying dumping trucks to the excavator is that with a loop turn and with a single install of a dumping truck for loading.

As a rule, in the investigated extremely deep iron ore open mine, the overburden of ledges from one of their flanks is used. Therefore, when working out ledges with longitudinal panels having narrow working platforms, only the scheme for supplying dumping trucks to an excavator with a dead end turn can be used. Compared to the loop scheme of turning dumping trucks, the excavator downtime using the dead end scheme of turning dumping trucks can reach $25-30 \%$ of the working time [1].

The appropriateness of the transition to the working out ledges with transverse panels in steeply sloped layers can be checked only in the design calendar schedule of mining operations [18]. With traditional methods for designing the mining engineering system of open mines in the working area on each ledge, working platforms with a width of at least $40-45 \mathrm{~m}$ are left. As a rule, to perform mining and geometric analysis, it is necessary to set the contours of working out stages that are detached from bottom position of the open mine pit almost on each open mine deepening horizon.

In the transition to working out of the steeply inclined fields with steeply sloped layers, the determining parameter is its width equal to the width of the transverse panel and determining the high-performance use of excavator-automobile complexes. In this case, the bottom position of the next stage 
of working out will depend on the possibility to perform mining and preparatory works and may not be accompanied without deepening an open mine. The spatial position of steeply sloped layers depends on the contours of the ore body bedding.

The open mine cross-section with steeply sloped bedding is represented in a form of a trapezoid $A D F E$ (Fig. 3). Here, $A B E$ is the mark of the left hanging open mine side, and $C D F$ is the mark of the right lying open mine side. $B C F E$ means ore body, and marks $\delta_{1}$ and $\delta_{r}$ - respectively, the open mine side slope angles at hanging and lying borders of a mineral bedding. The ore body incline angle $B E F$ is marked with $\beta$, and the working out stages - with $t=1,2, \ldots, N$. It can be seen from Fig. 3 that the number of stages is equal to the number of horizons and each horizon consists of sub-horizons - upper and lower ones. Starting from the upper horizon the serial number of sub-horizons is marked with $j$. It is obvious that $j=1,2, \ldots$, $2 \cdot N$. For a stage marked with $t$ the upper horizon has the number $2 t-1$, and the lower horizon $-2 t$. Open mine height in general is $H$, and the height of each sub-ledge is $h_{b}$.

The task of forming the contours of stages during the working out of high ledges with transverse panels in steeply sloped layers is described using the nonlinear programming method, which enables to take into account the configuration of mineral bedding for an even distribution of mining operation volumes. Bringing the final software product to an automated implementation mode will provide a solution for an optimal control of Bellman's dynamic programming method.

Let us introduce the following designations:

$S_{l}(i, j ; t)$ - the square of the open mine side figure from the hanging side of the field bedding;

$S_{r}(i, j ; t)$ - the square of the figure from the lying side of the filed bedding.

Here $i$ is the serial number of the horizon figure $j ; t$ is the serial number of the field development stage. To ensure equal volumes of mining in each panel of the BCFE area, we require that the following equality should take place

$$
U(t) \equiv \sum_{i} \sum_{j} S_{l}(i, j ; t)=\sum_{i} \sum_{j} S_{r}(i, j ; t), \quad t=2,3, \ldots, N .
$$

The mark $U(t)$ refers to the volume of excavated soil with ore at the development stage $t$. Let us use the symbols $U_{g}(t)$, $U_{r}(t)$ for respectively extracted volumes of overburden and ore at the development stage $t$. This equality is followed from the input designations

$$
U_{g}(t)+U_{r}(t)=2 U(t) .
$$

Accounting for the input designations the current overburden ration can be determined with the formula

$$
K(t)=\frac{U_{g}(t)}{U_{r}(t)}, t=1,2, \ldots, N .
$$

The main goal of our study is the optimization of the overburden ratio $K(t)$. The mathematical model for solving this task by the nonlinear programming method is described in

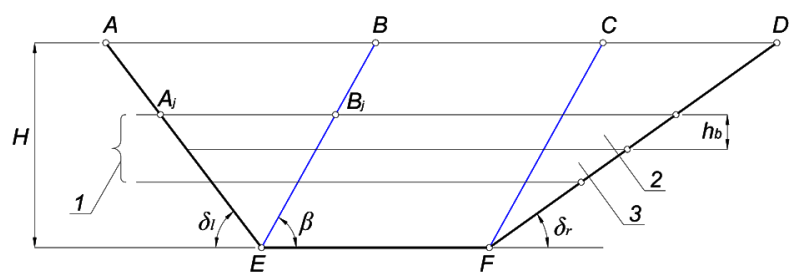

Fig. 3. Cross-section of an open mine with the steeply sloped bedding contour:

1 - horizon under the number of $t ; 2$ - the first sub-horizon under the number of $j=2 t-1 ; 3$ - the second sub-horizon under the number of $j=2 t$
[19]. In the present study, the optimal value of the overburden ratio is determined by the method of dynamic programming. The fact is that when implementing the nonlinear programming method, we experienced some difficulties associated with a large number of unknown values and nonlinearity of tasks. As a result, the software product becomes too cumbersome, with a complicated implementation algorithm. To solve this problem, this study suggests carrying out optimization work in another way, namely, using the optimal control method.

The main idea of our approach is that we divide the nonlinear programming task into two successively solved tasks for optimization. The first task aims at determining an optimal volume of extracted overburden rock and ore at each stage of mining. The second task aims at determining extracted volumes of overburden rock and ore at each horizon and subhorizon of the open mine. In this case, the optimal control task is again solved.

The optimal overburden value. It follows from the practical sense of the volume $U_{g}(t)$ that at each mining stage we need to strive to reach a minimal volume of the overburden extraction. But on the other hand, from the point of view of mining technology, the entire overburden volume should be extracted at the end of the stage $N$. Therefore, we will minimize the functional

$$
J\left(X_{g}, U_{g}\right)=\sum_{t=1}^{N} J_{t}\left(X_{g}(t-1), U_{g}(t)\right)
$$

where $X_{g}=\left(X_{g}(1), X_{g}(2), \ldots, X_{g}\left(t_{0}\right)\right)$ is so-called set of states, in our case this is the state of extracted overburden volume. Each components of the vector $X_{g}$ is the positive value, therewith the inequality should take place

$$
X_{g}(1)<X_{g}(2)<\ldots<X_{g}(N) .
$$

Here $X(t)$ is the summarized volume of extracted overburden mass until the stage, including $t$.

$U_{g}=\left(U_{g}(2), U_{g}(3), \ldots, U_{g}(N)\right)$ is a set of control vectors, which is called the control of field development processes. We start the optimization task with the stage when ore mining from the open mine begins along with the overburden excavation. Therefore, the sum in the functional (2) starts from $t=1$. It follows that

$$
X_{g}(N)=S_{A B E}+S_{C D F}-U_{g}(0)
$$

It should be noted that the overburden extracted volume at the zero stage $U_{g}(0)$ is considered to be the known value in the process of solving optimal control tasks. Based on it, we consider that $X_{g}(N)$ is the set known value. On the other hand, the value $X_{g}(0)$ of extracted overburden volume at the stage $t=1$ is also considered to be set.

The function $J_{t}\left(X_{g}(t-2), U_{g}(t)\right)$ under the sum sign in formula (2) depends on two variables: $X_{g}(t-1)$ - the summarized volume of extracted overburden mass until and including the stage $t-1 ; U_{g}(t)$ - the volume of the extracted overburden mass at the stage $t$.

The intention of an optimal control tasks is to minimize the sum (2) by controlling the values $U_{g}(t)$. As the function $J\left(X_{g}, U_{g}\right)$ is separable, the dynamic programming method developed by Bellman [20] is applicable to minimize the functional (2).

Solution. To minimize the extracted overburden volume, it is necessary to solve an optimal level task

$$
\begin{gathered}
J\left(X_{g}, U_{g}\right)=\sum_{t=1}^{N} \frac{U_{g}(t)}{X_{g}(t-1)} \rightarrow \min ; \\
X_{g}(t)=X_{g}(t-1)+U_{g}(t) .
\end{gathered}
$$

Here $X_{g}(0)$ is the extracted overburden volume at the zero mining stage. The extracted overburden volume at the end of 
the field development is: $X_{g}(N)=S_{A B E}+S_{C D F}+M \cdot h_{b}=S_{g}$ units (Fig. 3). Therefore, the inclusions take place

$$
X_{g}(t) \in\left[X_{g}(0), S_{g}\right] \equiv X, U_{g}(t) \in\left[0, S_{g}-X_{r}(0)\right] \equiv U .
$$

We use here $X$ and $U$ to mark a set of permissible values corresponding to the states $X_{g}(t)$ and controls $U_{g}(t)$. It means that an optimal solution for system (4-5) can be found in a way that the inclusions could take place as follows: $X_{g}^{*}(t) \in X, U_{g}^{*}(t) \in U, t=1,2,3, \ldots, N$.

It is known that Bellman's method consists of two parts: conditional and unconditional optimization. Performing the conditional and unconditional optimization after some transformations, we obtain a solution to the tasks (4-5). Thus,

The $1^{\text {st }}$ formula. Initial optimal value of the extracted overburden volume makes

$$
X_{g}^{*}(0)=X_{g}(0) .
$$

The $2^{\text {nd }}$ formula. Optimal value of the extracted overburden mass at the stage $t$ and the total volume of the extracted overburden mass for the entire period $t$ respectively make

$$
\begin{gathered}
U_{g}^{*}(t)=\left(X_{g}^{*}(t-1)\right)^{\frac{N-t}{N-t+1}}\left(S_{g}\right)^{\frac{1}{N-t+1}}-X_{g}^{*}(t-1) \\
X_{g}^{*}(t)=\left(X_{g}^{*}(t-1)\right)^{\frac{N-t}{N-t+1}}\left(S_{g}\right)^{\frac{1}{N-t+1}}, \quad t=1,2,3, \ldots, N .
\end{gathered}
$$

We can obtain from the (6) and (7) at the last development stage

$$
\begin{gathered}
U_{g}^{*}(N)=S_{g}-X_{g}^{*}(N-1) ; \\
X_{g}^{*}(N)=X_{g}^{*}(N-1)+U_{g}^{*}(N)=S_{g} .
\end{gathered}
$$

These expressions prove that after $N$ stages of working out the whole overburden volume is extracted from the open mine. We developed the method for finding $\min X_{s}(t)$ and obtained a simple calculation formula, as a result of which the optimal control task is easily programmed, which will be used later.

Based on the distinction between the concepts of the nearedge and deep zones of deep open mines and the introduction of two new parameters for the relationship between the contours of the ore field and the dynamics of the open mine formation, a method for substantiating the spatial position of the staged contours of the steeply sloped layers on the roundshaped open mine fields is presented hereby.

The main parameters of an open mine are its depth, the slope angles of its sides, its width and length along the bottom and the surface, the volume of rock mass and minerals within the contour of an open mine. The depth of the open mine is determined by the economic feasibility of the field development. Depending on the open mine depth, the type of excavation and transport equipment may vary. Its parameters influence the width and the length of the open mine along the bottom and the slope angles of the open mine sides. At a certain depth of the open mine, the slope angles of its sides should ensure a stable position of the mine excavations. The width and length of the open mine along the surface, as well as the volume of the rock mass within the open mine contours also depend on the open mine depth, the slope angles of its sides, the width and length along the bottom. At the same time, the volume of minerals within the open mine contours depends not only on the open mine depth, but also on the space position of the contour in relation to spreading and horizontal thickness of the ore bedding.

Thus, in conditions of flat terrain for the equal depth of the field development, the parameters of the open mine contours are unchanged, regardless of its position in space, which means that the volume of rock mass within the open contours is a constant value. The optimal position of the open mine in space in relation to the ore bedding is determined by the maxi- mal share of mineral in the volume of rock mass within the open mine contours.

It is proposed to count on the contours of the deep open mines where combined transport is applied by extension in such a way, that it is possible to form an idle side in design position at the bedding end in order to create a series of conveying transport.

The position of the open mine contours relative to the horizontal thickness of the field is recommended to calculate basing on the parameters of the near-contour zone of the field. The near-contour zone of the field is a part of a mineral bedding that does not relate to the volume of rock mass within the open mine contours and is located above its bottom mark.

The optimal position of the open mine contours of a certain depth relative to the horizontal thickness of the field should be considered such that have a minimal volume of the near-contour zone of the field. The parameter characterizing this position leads the reference point from the crossing point of the mineral contour line in the lying side and the surface to the upper edge of the open mine side in the lying side of the ore body $\left(b_{x}\right)$.

The position of the current open mine contours is determined taking into account the established design contours by the parameter $b^{\prime}-$ the distance between the crossing points of the surface with the contour lines of the mineral and the open mine side in the lying side.

The methods for calculating the parameters, determining the open mine contour position in $b_{x}$ and $b^{\prime}$, is as follows. First of all the values of the following parameters should be defined: open mine depth $\left(H_{D}, \mathrm{~m}\right)$, width $\left(b_{n}, \mathrm{~m}\right)$, length $\left(l_{n}, \mathrm{~m}\right)$ at the bottom of the open mine, horizontal thickness of the ore body $m_{h}$, ore body sloping angle $(\gamma, \mathrm{deg})$, slope angles of the open mine sides at lying, hanging sides and at the end of the mineral bedding ( $\beta_{l k}, \beta_{h k}, \beta_{1}, \beta_{2}$, degrees). Accounting for these parameters the volume of the near-contour zone of the field for the open mine depth $\left(H_{D}, \mathrm{~m}\right)$ and the function limits are defined $V_{c}=f\left(b_{x}\right)$

$$
H_{D}\left(\operatorname{ctg} b_{1 k}-\operatorname{ctg} \gamma\right)-m_{d}+b_{x} \leq H_{D}\left(\operatorname{ctg} \beta_{l k}-\operatorname{ctg} \gamma\right) .
$$

Then the function chart is built $V_{c}=f\left(b_{x}\right)$, based on which such parameter $b_{x}$ is applied at which $V_{c} \rightarrow \min$ (Fig. 4).

$$
\begin{gathered}
V_{c}=0.1805 b_{x}^{2}-97.528 b_{x}+14911 ; \\
b_{x}=-\frac{-97.528}{2 \cdot 0.1805}=270.16 .
\end{gathered}
$$

Then the parameters of the field development depth are defined $\left(H_{k}, \mathrm{~m}\right)$, width $\left(b_{k}, \mathrm{~m}\right)$, length $\left(l_{k}, \mathrm{~m}\right)$ at the bottom of the open mine area, slope angles of working sides in lying, hanging sides and at the end of the ore body $\left(\beta_{l c}, \beta_{h c}, \alpha_{p}\right.$, degrees). Accounting for these parameters, parameter $b x$ and parameters for its calculation the values $V_{c}$ for different mining depths $\left(H_{k}\right)$ and limits of the function $V_{c}=f\left(b^{\prime}\right)$

$$
H_{k}\left(\operatorname{ctg} \beta_{l k}-\operatorname{ctg} \gamma\right)-m_{h}+b_{k} \leq b^{\prime} \leq H_{k}\left(\operatorname{ctg} \beta_{l k}-\operatorname{ctg} \gamma\right) .
$$

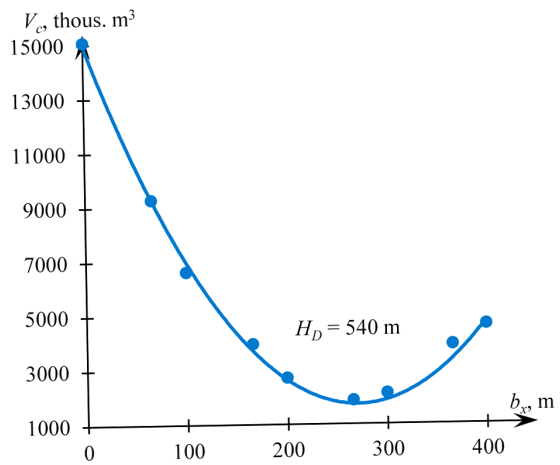

Fig. 4. Chart of the function $V_{c}=f\left(b_{x}\right)$ 
Then the charts of the function $V_{c}=f\left(b^{\prime}\right)$ are built for different values $H_{k}$. The values of parameters $b^{\prime}$ are defined from these charts, at which $V_{c} \rightarrow \min$ (Fig. 5).

Using the proposed method, the optimal position of the contour of the open mine, where the iron ore field is developed, was determined (Fig. 6) Using the optimization method, the parameters were calculated (Table).

To simplify the calculation algorithm when optimizing the position of the sides of the steeply sloped layers, Bellman's optimal control method in dynamic programming should be used. The contours of steeply sloped layers, built according to the above given methods, enable to distribute evently the remaining mineral reserves over the mining stages to obtain the most optimal mining work schedule for the existing particularly significant iron ore open mine.

Initially, we determine the required productivity of overburden operations. Due to the lagging of the overburden operations, the ore productivity for the first two stages is assumed to be 15 million tons per year. The planned ore productivity for 2019 amounted at 14.800 million tons with a productivity of overburden operations 97.789 million tons. The current overburden ratio reached 6.61 tons/ton.

The mining work schedules obtained from pre-built staged contours required to find reserves for transferring a part of the overburden rock volumes of stages 1 and 2 to the stage 3 .

Analysis of the mining work schedule (Fig. 7) shows that the greatest difficulties arise in the first three years - 20202022. The current overburden ratio at ore mining of 15 million tons will vary from 8.9 to 8.7 tons/ton. But taking into account the existing overburden lag, it can be reduced by almost $25 \%$. A two-fold decrease in the rock overburden volumes in 2023 will increase the ore mining by $30 \%$ up to 19.5 million tons, and in 2024 , by $60 \%$, respectively, and to develop a design ca-

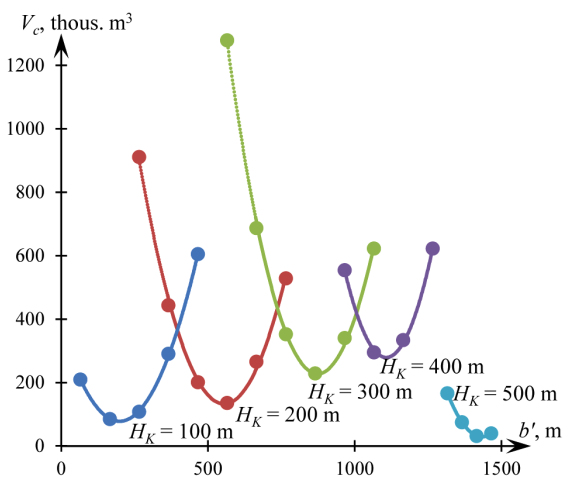

Fig. 5. The chart of the function $V_{c}=f\left(b^{\prime}\right)$ in conditions of the Yeristovsky mining and processing plant

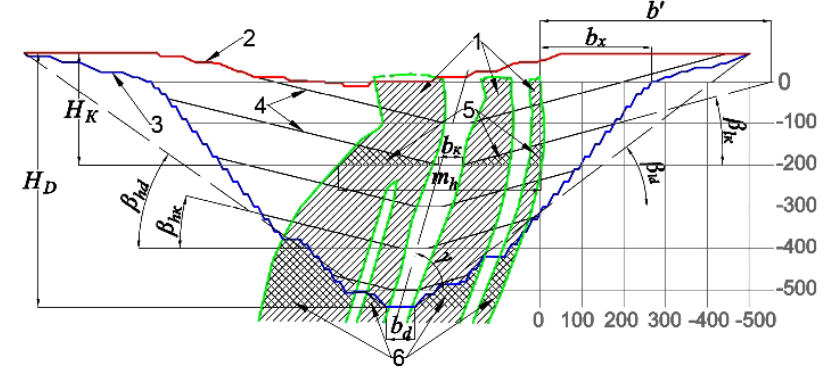

Fig. 6. Cross-section of the iron ore field:

1 - the mineral field; 2 - current position of the open mine contour; 3 - designed position of the open mine contour; 4- suggested position of the open mine contour; 5 - near-contour zone of the field at the optimal position of the current open mine contour; 6 near-contour zone of the field at the optimal position of the end open mine contour

Table

Results of the calculations of parameters of the near-contour zone

\begin{tabular}{|c|c|c|}
\hline$H_{K}, \mathrm{~m}$ & $V_{n p}^{\prime}=f\left(b^{\prime}\right)$ & $b^{\prime}, \mathrm{m}$ \\
\hline 100 & $V_{c}=0.0074 b^{\prime 2}-2.9419 b^{\prime}+369.92$ & 198.65 \\
\hline 200 & $V_{c}=0.0092 b^{\prime 2}-10.194 b^{\prime}+2961.9$ & 554.02 \\
\hline 300 & $V_{c}=0.011 b^{\prime 2}-19.22 b^{\prime}+8624$ & 873.64 \\
\hline 400 & $V_{c}=0.0137 b^{\prime} 2-30.354 b^{\prime}+17083$ & 1107.81 \\
\hline 500 & $V_{c}=0.01 b^{\prime 2}+28.608 b^{\prime}+20531$ & 1430.4 \\
\hline
\end{tabular}

pacity which makes 24 million tons. However, accounting for the present lag of the overburden operations compared to the design scheme of working out ledges with longitudinal panels for the period, when the production capacity is reached, it can be reduced almost by $25 \%(25.8 \%)$.

Compared to the mining design scheme, the production capacity development period will be reduced by 3 years, even taking into account its increase by 1 million tons of ore per year.

The increase in design capacity by 1 million tons of ore since 2024 is associated with the discharge of other open mines of the complex, most part of the mining equipment of which will be involved at this open mine in the period of 2019-2023, with the re-equipment to more powerful modern mining and transportation facilities that were not earlier provided in the working project, as well as the implementation of the technology of working out overburden rock in steeply sloped layers with transverse panels, significantly reducing the current spac-

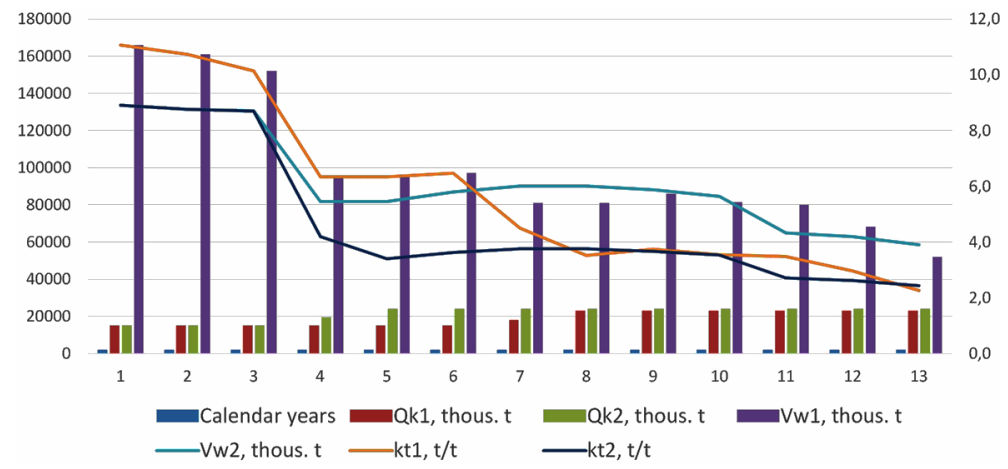

Fig. 7. Comparative chart of the calendar mining work schedules at transferring for working out ledges with transverse panels in steeply sloped layers and working out ledges with longitudinal panels according to designed scheme, where:

$Q_{k 1}, Q_{k 2}, V_{w 1}, V_{w 2}, k_{t 1}, k_{t 2}$ - annual ore and overburden productivities of the open mine, current overburden ratio according to designed and advisable variants, respectively 
ing of the single open mine sides with an increase in the length of the work face of each ledge.

It should also be noted that with deepening of mining operations, the open mine development in two separate sections, which was justified in the initial period of the field development, complicates the tracing of the opened excavations in cramped conditions, even with the use of automotive vehicles. The gradual transition to the development of reserves of both sites within a single open mine will allow carrying out mining operations with transverse panels in steeply sloped layers more intensively.

\section{Conclusions.}

1. Finding the required values with ensuring the optimal schedule of mining operation regime is achieved by formulation of a task using the nonlinear programming method. Automation of calculations for optimizing parameters of the design of the working sides in the dynamics of the mining work development using the method of nonlinear programming in such task formulation is provided by splitting it into two sequentially solved optimization tasks by the dynamic programming method on the basis of Bellman's optimality principle. In this case, the width of the panels, both at the stages of mining and from all sides of the open mine, will optimize the mining operation regime through a smooth uniform change of the current overburden ratio.

2. It was established that the lowest average overburden ratio is achieved with a minimal value of the sum of the ore volumes of the near-contour zone of the lying and hanging sides of the mineral bedding in the design position. The lowest current overburden ratio is achieved at a minimal value of the sum of the ore volumes of the near-contour zone of the lying and hanging sides of the mineral bedding as well as the working side of the open mine in the current position. The distance from the design contour of the open mine in the lying side to the intersection of the mineral contour line of the lying side and the surface affects the choice of an appropriate position of the design contours of the open mine, and the distance from the upper edge of the open mine side in the lying side in the design position to the upper edge of the open mine side in the lying side in the current position changes with the development of mining operations and affects the current position of the open mine contours.

3. It has been proved that with a significant lag of the overburden operations to approaching the limit surface contour of a deep and extremely deep open mine to maintain ore production capacity, there is almost no alternative for transferring to working out of the overburden rock mass and ore mining by transverse panels in steeply sloped layers from top to bottom. The period for the development of ore production capacity will be reduced by 3 years, and the overburden ratio for this period (within 7 years according to the design scheme) will decrease on average by $25.8 \%$.

4. With the width of the transverse panel within 60-80 m of the studied technology for working out ledges of the rock overburden and ore mining, the most expedient is the scheme for supplying automotive dumping trucks to an excavator with a loop turn and with a single install of the dumping truck for loading. Compared to the dead-end turn of the automotive dumping trucks using the technology for working out ledges with longitudinal panels, the transferring to working them out with transverse panels with a loop turn of the automotive dumping trucks for loading will increase the productivity of excavators by $25-30 \%$, which, along with a decrease in the open mine side spacing, compensates the intensity of excavation of the ore bedding from top to bottom within the boundaries of steeply sloped layers.

5. The transformation of the results of mining and geometric analysis in the implementation of the technology for working out ledges of the rock overburden and ore mining by transverse panels in steeply sloped layers within a single open mine enabled to obtain a production calendar for mining op- erations. In the period of 2020-2022, within the range of stages 1 and 2, the annual ore productivity of the Kacharsky open mine was taken equal to 15 million tons. The current overburden ratio in this period will make $8.9,8.76$ and 8.7 tons/ton, respectively. To reduce it in relation to the existing lag of overburden operations almost by $25 \%$, some of the loose overburden rock volumes were transferred to stage 3 . This share of $25 \%$ takes into account the transition to the working the overburden rock with transverse panels in steeply sloped layers.

The article was prepared according to the GF Ministry of Education and Science of the Republic of Kazakhstan 2018/ AR05133548

\section{References.}

1. Gumenik, I., Lozhnikov, A., \& Maevskiy, A. (2012). Methodological principles of negative opencast mining influence increasing due to steady development. Geomechanical Processes During Underground Mining, 45-49. https://doi.org/10.1201/ b13157-9.

2. Anisimov, O., Symonenko, V., Cherniaiev, O., \& Shustov, O. (2018). Formation of safety conditions for development of deposits by open mining. E3S Web of Conferences, 60, 00016. https://doi.org/10.1051/e3sconf/20186000016.

3. Halatchev, R. (2013). Owner-operator versus contractor production scheduling - a vision for the effective exploitation of Australian gold resources by surface mining. World gold conference in Brisbane, $Q L D$. Retrieved from https://old.ausimm. com.au/worldgold2013/docs/worldgold2013_registration brochure.pdf.

4. Afrapoli, A. M., \& Askari-Nasab, H. (2019). Mining fleet management systems: a review of models and algorithms. International journal of mining reclamation and environment, (33), 42-60. https://doi.org/10.1080/17480930.2017.1336607.

5. Elahizeyni, E., Kakaie, R., \& Yousefi, A. (2011). A new algorithm for optimum open pit design: Floating cone method III. Journal of Mining \& Environment, 2/2, 118-125.

6. Moniri-Morad, A., Pourgol-Mohammad, M., Aghababaei, H., \& Sattarvand, J. (2019). Capacity-based performance measurements for loading equipment in open pit mines. Journal of central south university, (26), 1672-1686. https://doi. org/10.1007/s11771-019-4124-5.

7. Morales, N., \& Reyes, P. (2016). Increasing the value and feasibility of open pit plans by integrating the mining system into the planning process. Journal of the Southern African Institute of Mining and Metallurgy, 116(7), 663-672. https://doi. org/10.17159/2411-9717/2016/v116n7a8.

8. Saavedra-Rosas, J., Jelvez, E., Amaya, J., \& Morales, N. (2016). Optimizing open-pit block scheduling with exposed ore reserve. Journal of the Southern African Institute of Mining and Metallurgy, 116(7), 655-662. https://doi.org/10.17159/24119717/2016/v116n7a7.

9. Samavati, M., Essam, D., Nehring, M., \& Sarker, R. (2017). A local branching heuristic for the open pit mine production scheduling problem. European Journal of Operational Research, 257(1), 261-271. https://doi.org/10.1016/j. ejor.2016.07.004.

10. Daduna, H., Krenzler, R., Ritter, R., \& Stoyan, D. (2016). Heuristic approximation and computational algorithms for closed networks: A case study in open-pit mining. $2^{\text {nd }}$ European Conference on Queueing Theory (ECQT), (119), 5-26. https://doi.org/10.1016/j.peva.2017.12.002.

11. Paricheh, M., \& Osanloo, M. (2019). Concurrent openpit mine production and in-pit crushing-conveying system planning. Engineering optimization. https://doi.org/10.1080/0 305215X.2019.1678150.

12. Chaowasakoo, P., Seppala, H., Koivo, H., \& Zhou, Q. (2017). Improving fleet management in mines: The benefit of heterogeneous match factor. European journal of operational research, (3), 1052-1065. https://doi.org/10.1016/j. ejor.2017.02.039. 
13. Chaowasakoo, P., Seppala, H., \& Koivo, H. (2018). Agebased maintenance for a fleet of haul trucks. Journal of quality in maintenance engineering, (4), 511-528. https://doi. org/10.1108/JQME-03-2017-0016.

14. Dabbagh, A., \& Bagherpour, R. (2019). Development of a Match Factor and Comparison of Its Applicability with AntColony Algorithm in a Heterogeneous Transportation Fleet in an Open-Pit Mine. Journal of Mining Science, (55), 45-56. https://doi.org/10.1134/S1062739119015287.

15. Adams, K. K., \& Bansah, K. J. (2016). Review of Operational Delays in Shovel-Truck System of Surface Mining Operations. $4^{\text {th }}$ UMaT Biennial International Mining and Mineral Conference, 60-65. Retrieved from https://www.researchgate. net/publication/306060370_Review_of_Operational_Delaysin_ShovelTruck_System_of_Surface_Mining_Operations.

16. Abbaspour, H., Drebenstedt, C., \& Dindarloo, S.R. (2018). Evaluation of safety and social indexes in the selection of transportation system alternatives (Truck-Shovel and IPCCs) in open pit mines. Safety science, (108), 1-12. https:// doi.org/10.1016/j.ssci.2018.04.020.

17. Kuzmenko, S.V., Kaluzhnyi, Ye.S., Moldabayev, S. K., Shustov, O. O., Adamchuk, A. A., \& Toktarov, A. A. (2019). Optimization of the position of the complexes of cyclic-flow technology in the refinement of deep iron ore quarries. Mining of Mineral Deposits, 13(3), 104-112. https://doi.org/10.33271/ mining13.03.104.

18. Kalybekov, T., Rysbekov, K. B., Sandibekov, M. N., Zhakypbek, Y., \& Begymzhanova, Y. Y. (2020). The study of rational technology of reclamation of the mine-out quarry space. Journal of Advanced Research in Natural Sience, 9, 63-70. https://doi.org/10.26160/2572-4347-2020-9-63-70.

19. Moldabayev, S., Rysbaiuly, B., \& Sultanbekova, Zh. (2013). Justification outlines steps mining steep deposits solution of the nonlinear programming. Mining of Mineral Deposits, 7, 241-246.

20. Moldabayev, S., Rysbaiuly, B., Sultanbekova, Zh., \& Sarybayev, N. (2019). Methodological approach to creation of the 3D model of an oval-shaped open pit mine. E3S Web of Conferences, (123), 00013. https://doi.org/10.1051/e3sconf/201912301049.

\section{Апробація технології ефективного застосування екскаваторно-автомобільних комплексів у глибоких кар'єрах}

\section{С. К. Молдабаєв ${ }^{1}$, А.А. Адамчук ${ }^{2}$, А.А. Токтаров ${ }^{1}$, Е. Абен ${ }^{1}$, О. О. Шустов ${ }^{2}$}

1 - Satbayev University, м. Алмати, Республіка Казахстан, e-mail: s.moldabayev@satbayev.university

2 - Національний технічний університет «Дніпровська політехніка», м. Дніпро, Україна, e-mail:a.a.adamchuk93@ gmail.com

Мета. Встановити доцільність реалізації технології відпрацювання уступів порід скельного розкриву й руди поперечними панелями у крутонахилених шарах єдиним кар'єром до кінця його експлуатації.

Методика. При обгрунтуванні просторового положення поетапних контурів крутонахилених шарів на кар'єрних полях округлої форми та їх оптимізації використовувалися наступні методи: аналітичний та оптимального управління Беллмана в динамічному програмуванні в комплексі з інтегрованим гірничо-геологічними інформаційним комплексом на цифровій моделі залізорудного родовища. Для дослідження резервів збільшення продуктивності екскаваторного-автомобільних комплексів, при переході на технологію відпрацювання уступів поперечними панелями у крутонахилених шарах зверху вниз зі зменшенням розносу бортів кар'єру, вико- ристовувалися методи кореляційного й регресійного аналізів.

Результати. На підставі розмежування понять приконтурної та глибинної зон глибоких кар'єрів і введення двох нових параметрів взаємозв'язку контурів рудного покладу й динаміки формування кар'єра розроблено метод обгрунтування просторового положення поетапних контурів крутонахилених шарів на кар'єрних полях округлої форми. У порівнянні з тупиковим розворотом автосамоскидів по використовуваній технології відпрацювання уступів поздовжніми панелями, перехід на їх відпрацювання поперечними панелями, шириною в межах 60-80 м, з петльовим розворотом автосамоскидів на навантаження дозволить збільшити продуктивність екскаваторів мінімум на 25-30 \%, що, поряд зі зменшенням розносу бортів кар'єру, компенсує інтенсивність розкриття рудного покладу зверху вниз у межах крутонахилених шарів навіть при значному відставанні розкривних робіт.

Наукова новизна. Перехід на технологію відпрацювання уступів поперечними панелями у крутонахилених шарах є єдиним рішенням при перевищенні відставання розкривних робіт відносно проектних поточних обсягів розкриву при підході гірничих робіт до граничного контуру кар'єра по поверхні. На досліджуваному надглибокому залізорудному кар'єрі навіть при перевищенні більш ніж у 3 рази проектного обсягу поточного (річного) розкриву, ця технологія дозволила зменшити обсяг розкривного відставання на $25 \%$ і скоротити термін освоєння виробничої потужності по руді 3 8-ми до 5-ти років. Створена математична модель 3 оптимізації контурів етапів відпрацювання для крутоспадних родовищ при відпрацюванні уступів поперечними панелями у крутонахилених шарах, в якій функціонал містить у собі нелінійність четвертого порядку щодо шуканої величини - ширини панелей. Автоматизація розрахунків з оптимізації параметрів конструкції робочих бортів у динаміці розвитку гірничих робіт за такої постановки завдання методом нелінійного програмування забезпечується розщепленням ії̈ на дві послідовно вирішувані оптимізаційні задачі методом динамічного програмування за принципом оптимальності Беллмана.

Практична значимість. Відбудовані з використанням розробленого методу обгрунтування просторового положення поетапні контури крутонахилених шарів для діючого залізорудного кар'єру після оптимізації параметрів крутих бортів 3 використанням методу оптимального управління Беллмана дозволили отримати реальний календарний графік ведення гірничих робіт при реалізації технології відпрацювання уступів по породам скельного розкриву й руди поперечними панелями єдиним кар'єром. Встановлено, що, незважаючи на збільшення обсягу гірничої маси в панелі, яка відпрацьовується зверху вниз, вдається значно нівелювати обсяги відставання розкривних робіт і скоротити період освоєння виробничої потужності для стратегічного об'єкта з видобутку залізної руди. Аналіз календарного графіка гірничих робіт показує, що найбільші труднощі виникають у перші три роки - 2020-2022 роки. Поточний коефіцієнт розкриву при продуктивності 15 млн т. буде змінюватися від 8,9 до 8,7 т./т. Але з урахуванням наявності відставання розкривних робіт його вдасться зменшити майже на $25 \%$. Двократне зменшення обсягів скельного розкриву в 2023 році дозволить збільшити видобуток руди на $30 \%$ - до 19,5 млн т., а у 2024 році відповідно, на $60 \%$ і освоїти проектну потужність в 24 млн т.

Ключові слова: глибокий кар'єр, розкривні і видобувні роботи, крутопохилі шари, поперечні панелі, автомобільний транспорт, екскаваторного-автомобільний комплекс 


\section{Апробация технологии эффективного применения экскаваторно-автомобильных комплексов в глубоких карьерах}

\author{
С. К. Молдабаев ${ }^{1}$, А. А. Адамчук ${ }^{2}$, А. А. Токтаров ${ }^{1}$ \\ Е. Абен ${ }^{1}$, А. А. Шустов ${ }^{2}$
}

1 - Satbayev University, г. Алматы, Республика Казахстан, e-mail: s.moldabayev@satbayev.university

2 - Национальный технический университет «Днепровская политехника», г. Днепр, Украина, e-mail: a.a.adamchuk93@gmail.com

Цель. Установить целесообразность реализации технологии отработки уступов пород скальной вскрыши и руды поперечными панелями в крутонаклонных слоях единым карьером до конца его эксплуатации.

Методика. При обосновании пространственного положения поэтапных контуров крутонаклонных слоев на карьерных полях округлой формы и их оптимизации использовались следующие методы: аналитический и оптимального управления Беллмана в динамическом программировании в комплексе с интегрированным горногеологическим информационным комплексом на цифровой модели железорудного месторождения. Для исследования резервов увеличения продуктивности экскаваторно-автомобильных комплексов, при переходе на технологию отработки уступов поперечными панелями в крутонаклонных слоях сверху вниз со смещением разноса бортов карьера, использовались методы корреляционного и регрессионного анализов.

Результаты. На основании разграничения понятий приконтурной и глубинной зон глубоких карьеров и введения двух новых параметров взаимосвязи контуров рудной залежи и динамики формирования карьера разработан метод обоснования пространственного положения поэтапных контуров крутонаклонных слоев на карьерных полях округлой формы. По сравнению с тупиковым разворотом автосамосвалов по используемой технологии отработки уступов продольными панелями, переход на их отработку поперечными панелями, шириной в пределах 60-80 м, с петлевым разворотом автосамосвалов на погрузку, позволит увеличить производительность экскаваторов минимум на 25-30 \%, что, наряду с уменьшением разноса бортов карьера, компенсирует интенсивность вскрытия рудной залежи сверху вниз в границах крутонаклонных слоев даже при значительном отставании вскрышных работ.

Научная новизна. Переход на технологию отработки уступов поперечными панелями в крутонаклонных слоях является единственным решением при превышении отставания вскрышных работ относительно про- ектных текущих объемов вскрыши при подходе горных работ к предельному поверхностному контуру карьера. На исследуемом сверхглубоком железорудном карьере, даже при превышении более чем в 3 раза проектного объема текущей (годовой) вскрыши, эта технология позволила уменьшить объем вскрышного отставания на $25 \%$ и сократить срок освоения производственной мощности по руде с 8-и до 5-и лет. Создана математическая модель по оптимизации контуров этапов отработки для крутопадающих месторождений при отработке уступов поперечными панелями в крутонаклонных слоях, в которой функционал содержит в себе нелинейность четвертого порядка относительно искомой величины - ширины панелей. Автоматизация расчетов по оптимизации параметров конструкции рабочих бортов в динамике развития горных работ при такой постановке задачи методом нелинейного программирования обеспечивается расщеплением ее на две последовательно решаемые оптимизационные задачи методом динамического программирования на принципе оптимальности Беллмана.

Практическая значимость. Отстроенные с использованием разработанного метода обоснования пространственного положения поэтапные контуры крутонаклонных слоев для действующего железорудного карьера после оптимизации параметров крутых бортов с использованием метода оптимального управления Беллмана позволили получить реальный календарный график производства горных работ при реализации технологии отработки уступов по породам скальной вскрыши и руды поперечными панелями единым карьером. Установлено, что, несмотря на увеличение объема горной массы в отрабатываемой панели сверху вниз, удается значительно нивелировать объемы отставания вскрышных работ и сократить период освоения производственной мощности для стратегического объекта по добыче железной руды. Анализ календарного графика горных работ показывает, что наибольшие затруднения возникают в первые три года - 2020-2022 годы. Текущий коэффициент вскрыши при добыче руды по 15 млн т. будет изменяться от 8,9 до 8,7 т./т. Но с учетом имеющего место отставания вскрышных работ его удастся уменьшить почти на $25 \%$. Двукратное уменьшение объемов скальной вскрыши в 2023 году позволит увеличить добычу руды на $30 \%$ - до 19,5 млн т., а в 2024 году - соответственно, на $60 \%$ и освоить проектную мощность в 24 млн т.

Ключевые слова: глубокий карьер, вскрышные и добычные работы, крутонаклонные слои, поперечные панели, автомобильный транспорт, экскаваторно-автомобильный комплекс

Recommended for publication by V.I. Symonenko, Doctor of Technical Sciences. The manuscript was submitted 14.11.19. 